\title{
Are the blood groups of women with preeclampsia a risk factor for the development of hypertension postpartum?
}

\author{
Deniz Avci' \\ Hatice Karagoz ${ }^{2}$ \\ Ozerhan Ozer' \\ Kubra Esmeray' \\ Kadir Bulut ${ }^{\prime}$ \\ Fatma Aykas' \\ Ali Cetinkaya' \\ Emine Uslu' \\ Samet Karahan' \\ Mustafa Basak' \\ Abdulsamet Erden' \\ 'Internal Medicine Department, \\ Kayseri Training and Research \\ Hospital, ${ }^{2}$ Internal Medicine \\ Department, Acıbadem Kayseri \\ Hospital, Kayseri, Turkey
}

This article was published in the following Dove Press journal:

Therapeutics and Clinical Risk Management

19 April 2016

Number of times this article has been viewed

Introduction: Preeclampsia (PE) is a pregnancy-related disorder characterized by hypertension (HT) and proteinuria noticeable after 20 weeks of gestation. PE is now considered as a cardiovascular disease risk factor and a number of studies have shown that experiencing PE increases the prevalence of various cardiovascular risk factors, such as metabolic syndrome and HT. In this study, we aimed to investigate any possible relationship between the $\mathrm{ABO} / \mathrm{Rh}$ blood group system and PE in Turkey. In the second part of the study, we examined the relationship between the ABO blood group system and development of HT after PE.

Patients and methods: A total of 250 patients with PE from Kayseri Training and Research Hospital between 2002 and 2012 were included in the study. Patients were classified according to blood groups (A, B, AB, and O) and Rh status (+/-).

Results: There was a significant difference between the patients with $\mathrm{PE}$ and the control group in terms of distribution of $\mathrm{ABO}$ blood groups and the percentage of group $\mathrm{AB}$ was found to be higher in patients with $\mathrm{PE}$ compared to the control group $(P=0.029)$. The risk of developing $\mathrm{PE}$ was significantly higher in group $\mathrm{AB}$ than other blood groups $(P=0.006)$. The risk of developing HT after PE was significantly higher in group $\mathrm{O}$ than other blood groups $(P=0.004)$.

Discussion: In this study, we found that the patients with blood group $\mathrm{AB}$ have a higher risk for PE. The patients with PE of blood group $\mathrm{O}$ are at high risk of developing HT, and Rh factor was identified as another risk at this point and these patients should be closely followed postpartum.

Keywords: $\mathrm{ABO}$ blood groups, Rh factor, preeclampsia, proteinuria, pregnancy, hypertension, postpartum

\section{Introduction}

Preeclampsia (PE) is a pregnancy-related disorder characterized by hypertension (HT) and proteinuria noticeable after 20 weeks of gestation. ${ }^{1}$ It is a multisystem disorder that complicates $3 \%-8 \%$ of pregnancies in Western countries and a major cause of maternal mortality and morbidity, preterm birth, perinatal death, and intrauterine growth restriction. ${ }^{2}$ It can lead to problems in the liver, kidneys, brain, and the clotting system and, overall, 10\%-15\% of maternal deaths are directly associated with PE and eclampsia. ${ }^{3}$

The etiology of the disease is unknown, but recent studies have revealed that this disorder appears to originate in placenta and is characterized by widespread maternal endothelial dysfunction. ${ }^{1}$ Since the 19 th century, it was noticed that the PE cases cluster within some families and this suggests a genetic component but at present, no genetic test is available to predict this disorder. Because of the lack of a predictive
Correspondence: Abdulsamet Erden Internal Medicine Department, Kayseri Training and Research Hospital, Kayser Eğitim Araștırma Hastanesi, İç Hastalıkları Kliniği, 9. Blok 3. Kat, Kocasinan, Kayseri, 38010 , Turkey

Tel +905327803805

Email drsameterden@gmail.com
Therapeutics and Clinical Risk Management 2016:12 617-622

617

Dovepress

http://dx.doi.org/10.2147/TCRM.S100557 (c) (7) (2) 2016 Avci et al. This work is published and licensed by Dove Medical Press Limited. The full terms of this license are available at https://www.dovepress.com/terms.php
and incorporate the Creative Commons Attribution - Non Commercial (unported, v3.0) License (http://creativecommons.org/licenses/by-nc/3.0/). By accessing the work you

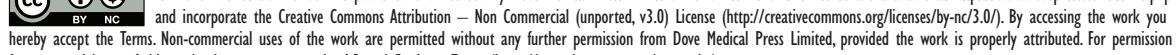
for commercial use of this work, please see paragraphs 4.2 and 5 of our Terms (https://www.dovepress.com/terms.php). 
test, careful monitoring and assessment of women, especially those in high-risk groups, are very important. High-risk groups include: previous history of PE, those at either end of the reproductive age spectrum, obesity, black ethnicity, primiparity, multiple pregnancy, and preexisting medical conditions - renal disease, insulin-dependent diabetes, autoimmune disease, and antiphospholipid syndrome. ${ }^{4}$

$\mathrm{PE}$ is now considered as a cardiovascular disease risk factor and number of studies have shown that experiencing PE increases the prevalence of various cardiovascular risk factors, such as metabolic syndrome, HT, insulin resistance, microalbuminuria, and endothelial dysfunction. ${ }^{5}$

The ABO blood group system was first discovered by Karl Landsteiner in 1900 when he was searching for the reason why some blood transfusions were successful while others could be deadly. The blood group of a person depends upon the presence or absence of two genes, A and B. The gene that determines human $\mathrm{ABO}$ blood type is located on chromosome 9 and is called ABO glycosyltransferase. ${ }^{6}$

No diseases are known to result from the lack of expression of ABO blood group antigens, but the susceptibility to a number of diseases has been interrelated to a person's ABO phenotype. Such correlations remain conflicting. For example, gastric cancer is more common in group A, whereas gastric and duodenal ulcers occur more commonly among blood group $\mathrm{O}$ individuals. ${ }^{7}$ Previously, many different results have been reported in other cancer types. ${ }^{8}$ The association of $\mathrm{ABO}$ blood groups with diabetes mellitus has been observed earlier in several epidemiological and genetic studies and resulted with inconsistent findings. ${ }^{7}$ No association has been observed between essential HT and $\mathrm{ABO}$ blood groups in a study, while another study showed that the blood group B was seen more in the HT and obesity. ${ }^{9,10}$

The relationship between $\mathrm{ABO} / \mathrm{Rh}$ blood groups and patients with $\mathrm{PE}$ has been observed in many studies for years, which resulted in conflicting findings. In this study, we aimed to investigate any possible relationship between the $\mathrm{ABO} / \mathrm{Rh}$ blood group system and PE in Turkey. In the second part of the study, we examined the relationship between the ABO blood group system and development of HT after PE.

\section{Patients and methods}

A total of 250 patients with PE from Kayseri Training and Research Hospital between 2002 and 2012 were included in the study. All of the patients signed an informed consent after being informed about the details of the study. This study was approved by the Kayseri Training and Research Hospital
Ethics Committee. The cases that have serologically determined blood groups and $\mathrm{Rh}$ factor in the hospital records were included in the study and the patients with unknown blood group were excluded. Patients were classified according to blood groups (A, B, AB, and O) and Rh status (+/-).

The patients with the following criteria were defined as PE: onset at $>20$ weeks' gestational age of 24-hour proteinuria $\geq 300 \mathrm{mg} /$ day or, if not available, a protein concentration $\geq 30 \mathrm{mg}$ ( $\geq 1+$ on dipstick) in a minimum of two random urine samples collected at least 4-6 hours but no more than 7 days apart; a systolic blood pressure $>140 \mathrm{mmHg}$ or diastolic blood pressure $\geq 90 \mathrm{mmHg}$ as measured twice, using an appropriate cuff, 4-6 hours and less than 7 days apart; and disappearance of all these abnormalities before the end of the sixth week postpartum. The patients who did not meet the diagnostic criteria were excluded.

The distribution of blood groups of the patients with PE was compared with the distribution of blood groups of healthy donors who were admitted to the Turkish Red Crescent Blood Service in Kayseri in the year 2012. Donors consisted of 17,314 healthy volunteers. After being compared with the healthy control group, the patients with the diagnosis of PE were examined for transitioning to overt HT postpartum by checking their drugs from the pharmacy data system in our country or by calling and inviting them to the hospital for the follow-up of blood pressure or 24-hour ambulatory blood pressure monitoring. The patients with systolic blood pressure $\geq 140 \mathrm{mmHg}$ and/or diastolic blood pressure $\geq 90 \mathrm{mmHg}$ were accepted as hypertensive. We evaluated the patients for HT at year 2014.

Statistical analysis was performed using the SPSS software version 16.0 (SPSS Inc., Chicago, IL, USA). Continuous variables were given as mean \pm standard deviation; categorical variables were defined as percentages. Qualitative variables are given as percent and for the correlation of the patients with $\mathrm{PE}$ and control group from the point of $\mathrm{ABO}$ blood groups. Chi-square test was used to compare categorical data. The relation among the groups of healthy control, PE, and HT patients following PE was examined by the chisquare test. A $P$-value $<0.05$ was considered significant. In the presence of three or more independent variables, ratios and percentages were used to determine which group had the biggest difference, and the similar groups were combined to create $2 * 2$ cross tables in order to evaluate the chi-square tests again (when the $P$-values were $<0.05$ in the multiwell chi-square tests). The other possible test was the binary comparison of the groups. Bonferroni correction was used when the groups were compared in doubles. 
Table I Comparison of $\mathrm{ABO}$ blood groups between the patients with preeclampsia and control groups

\begin{tabular}{lll}
\hline ABO blood groups* & $\begin{array}{l}\text { Patients with } \\
\text { preeclampsia, } \mathbf{n}(\%)\end{array}$ & $\begin{array}{l}\text { Control } \\
\text { group, } \mathbf{n}(\%)\end{array}$ \\
\hline $\mathrm{O}$ & $69(28)$ & $5,423(3 \mathrm{I})$ \\
$\mathrm{A}$ & $104(42)$ & $7,756(45)$ \\
$\mathrm{B}$ & $46(18)$ & $2,819(16)$ \\
$\mathrm{AB}$ & $31(12)$ & $1,316(8)$ \\
Total & $250(100)$ & $17,314(100)$ \\
\hline
\end{tabular}

Note: $* P=0.029$.

\section{Results}

The mean age of all patients with PE was $31.78 \pm 7.45$ years. Of the women who developed PE, 28\% had type O blood, $42 \%$ had type A blood, 18\% had type B blood, and 12\% had type AB blood, whereas those of control group (healthy donors) had $31 \%, 45 \%, 16 \%$, and $8 \%$, respectively. There was a significant difference between the patients with $\mathrm{PE}$ and control group in terms of distribution of $\mathrm{ABO}$ blood groups and the percentage of group $\mathrm{AB}$ was found to be higher in patients with $\mathrm{PE}$ compared to the control group $(P=0.029)$ (Table 1). This significance was attributed to the group AB because the percentage of group $\mathrm{AB}$ was $12 \%$ in the group with $\mathrm{PE}$ while it was $8 \%$ in the control group. So, the patients were divided into two groups as $\mathrm{AB}$ and non- $\mathrm{AB}$ in order to make subanalyses. The percentages of patients with $\mathrm{PE}$ for $\mathrm{AB}$ and non- $\mathrm{AB}$ groups were $12 \%$ and $88 \%$, whereas those of control group (healthy donors) were $8 \%$ and $92 \%$, respectively (Table 2). The risk of developing PE was significantly higher in group $\mathrm{AB}$ than other blood groups $(P=0.006)$.

Of the PE patients who did not develop HT, 25\% had type O blood, 44\% had type A blood, 19\% had type B blood, and $25 \%$ had type $\mathrm{AB}$ blood, whereas the patients who developed HT had 55\%, 20\%, 10\%, and 15\%, respectively. Of the 250 patients with PE, 20 patients have developed HT postpartum. There was a significant difference between the patients developing HT after PE and PE without HT in terms of distribution of $\mathrm{ABO}$ blood groups and the percentage of group $\mathrm{O}$ was found to be higher in patients developing HT after PE ( $P=0.026)$ (Table 3$)$. This significance was attributed to the group $\mathrm{O}$ because the percentage of group $\mathrm{O}$ was $55 \%$ in the group developing HT after PE while it was $25 \%$ in

Table 2 Comparison of $A B$ and non-AB (A, B, and $O)$ blood groups between the patients with preeclampsia and control groups

\begin{tabular}{lll}
\hline ABO blood groups* & $\begin{array}{l}\text { Patients with } \\
\text { preeclampsia, n (\%) }\end{array}$ & $\begin{array}{l}\text { Control } \\
\text { group, n (\%) }\end{array}$ \\
\hline AB & $31(12)$ & $1,316(8)$ \\
Non-AB & $219(88)$ & $15,998(92)$ \\
Total & $250(100)$ & $17,314(100)$ \\
\hline Note: $* P=0.006$ & &
\end{tabular}

Note: $* P=0.006$
Table 3 Comparison of $A B O$ blood groups between the preeclampsia patients with or without hypertension postpartum

\begin{tabular}{lll}
\hline $\begin{array}{l}\text { ABO blood } \\
\text { groups* }\end{array}$ & $\begin{array}{l}\text { Preeclampsia } \\
\text { patients with } \\
\text { hypertension } \\
\text { postpartum, } \mathbf{n}(\%)\end{array}$ & $\begin{array}{l}\text { Preeclampsia } \\
\text { patients without } \\
\text { hypertension } \\
\text { postpartum, } \mathbf{n}(\%)\end{array}$ \\
\hline $\mathrm{O}$ & $11(55)$ & $58(25)$ \\
$\mathrm{A}$ & $4(20)$ & $100(44)$ \\
$\mathrm{B}$ & $2(10)$ & $44(19)$ \\
$\mathrm{AB}$ & $3(15)$ & $28(12)$ \\
Total & $20(100)$ & $230(100)$ \\
\hline
\end{tabular}

Note: $* P=0.026$.

the group without HT. So, the patients were divided into two groups as $\mathrm{O}$ and non-O in order to make subanalyses. The percentages of patients with $\mathrm{PE}$ with $\mathrm{HT}$ for $\mathrm{O}$ and non-O groups were $55 \%$ and $45 \%$, whereas those of $\mathrm{PE}$ without HT were $25 \%$ and $75 \%$, respectively (Table 4 ). The risk of developing HT after PE was significantly higher in group $\mathrm{O}$ than other blood groups $(P=0.004)$.

When the blood group $\mathrm{O}$ was compared with other blood groups, the odds for developing HT after PE were found to be $1.22(11 / 9)$ and $0.33(58 / 172)$, respectively.

We calculated and added the risk ratio as $(0.55 / 0.25=2.2)$ and the odds ratio as $(1.22 / 0.33=3.69)$. The risk ratio and odds ratio reflect the risk for blood group $\mathrm{O}$.

The percentages of $\mathrm{O} R h(+), \mathrm{O} h(-), \mathrm{A} R(+), \mathrm{A} \mathrm{Rh}$ (-), B Rh (+), B Rh (-), AB Rh (+), and AB Rh (-) groups were $22 \%, 3 \%, 38 \%, 6 \%, 16 \%, 3 \%, 12 \%$, and $0 \%$, respectively, in the PE patients without HT, whereas those of PE patients with HT were $55 \%, 0 \%, 20 \%, 0 \%, 5 \%, 5 \%, 15 \%$, and $0 \%$, respectively (Table 5 ). There was a significant difference between the groups - PE patients with or without $\mathrm{HT}$ - in terms of ABO blood groups with Rh factor and as seen in Table 5, the ratio of developing HT is found to be higher in the patients with $+\mathrm{Rh}$ factor $(P=0.04)$.

As noted earlier, the risk of developing HT after PE was found to be higher in the group $\mathrm{O}$; this significance was attributed to the group $\mathrm{O} \mathrm{Rh}(+)$. So, the patients were divided into two groups $-\mathrm{O} \mathrm{Rh}(+)$ and non-O $\mathrm{Rh}(+)-$ in

Table 4 Comparison of $\mathrm{O}$ and non-O (A, B, and $\mathrm{AB}$ ) blood groups between the preeclampsia patients with or without hypertension postpartum

\begin{tabular}{lll}
\hline $\begin{array}{l}\text { ABO blood } \\
\text { groups* }\end{array}$ & $\begin{array}{l}\text { Preeclampsia } \\
\text { patients with } \\
\text { hypertension } \\
\text { postpartum, n (\%) }\end{array}$ & $\begin{array}{l}\text { Preeclampsia } \\
\text { patients without } \\
\text { hypertension }\end{array}$ \\
\hline postpartum, n (\%) \\
Non-O & $11(55)$ & $58(25)$ \\
Total & $9(45)$ & $172(75)$ \\
\hline
\end{tabular}

Note: $* p=0.004$. 
Table 5 Comparison of $\mathrm{ABO}$ blood groups and Rh factor between the preeclampsia patients with or without hypertension postpartum

\begin{tabular}{lll}
\hline $\begin{array}{l}\text { ABO blood } \\
\text { groups with } \\
\text { Rh factor* }\end{array}$ & $\begin{array}{l}\text { Preeclampsia } \\
\text { patients with } \\
\text { hypertension } \\
\text { postpartum, n (\%) }\end{array}$ & $\begin{array}{l}\text { Preeclampsia } \\
\text { patients without } \\
\text { hypertension } \\
\text { postpartum, } \mathbf{n}(\%)\end{array}$ \\
\hline O Rh (+) & II (55) & 5 I (22) \\
O Rh (-) & $0(0)$ & $7(3)$ \\
A Rh $(+)$ & $4(20)$ & $87(38)$ \\
A Rh $(-)$ & $0(0)$ & $13(6)$ \\
B Rh $(+)$ & $1(5)$ & $37(16)$ \\
B Rh $(-)$ & $1(5)$ & $7(3)$ \\
AB Rh $(+)$ & $3(15)$ & $28(12)$ \\
AB Rh $(-)$ & $0(0)$ & $0(0)$ \\
Total & $20(100)$ & $230(100)$ \\
\hline
\end{tabular}

Note: $* P=0.04$.

order to make subanalyses. The percentages of patients with $\mathrm{PE}$ with $\mathrm{HT}$ for $\mathrm{O} \mathrm{Rh}(+)$ and non-O Rh (+) groups were 55\% and $45 \%$ respectively, whereas those of $\mathrm{PE}$ without $\mathrm{HT}$ were $22 \%$ and $78 \%$, respectively. When the ABO blood groups and $+\mathrm{Rh}$ factor were evaluated together, the significance between the groups with or without HT was attributed to the group O Rh (+) (Table 6). The risk of developing HT after $\mathrm{PE}$ was significantly higher in group $\mathrm{O} \mathrm{Rh}(+)$ than other blood groups $(P=0.001)$.

\section{Discussion}

The relationship between $\mathrm{ABO} / \mathrm{Rh}$ blood groups and patients with PE has been observed in many studies for years which resulted in conflicting findings. For example, a study showed no difference for the risk of PE between the blood groups of $\mathrm{O}$ and $\mathrm{A}$, while another study observed increased risk of patients developing PE with blood group A. ${ }^{11,12}$ With respect to $\mathrm{ABO}$ and $\mathrm{Rh}$ blood groups, no differences between $\mathrm{PE}$ and controls were observed in a study from Brazil and again another study from Brazil showed no differences in blood group distribution between controls and PE. ${ }^{13,14}$

Table 6 Comparison of $O \mathrm{Rh}(+)$ and non-O Rh (+) (O Rh (-), A Rh (+), A Rh (-), B Rh (+), B Rh (-), AB Rh (+), and AB Rh (-) blood groups between the preeclampsia patients with or without hypertension postpartum

\begin{tabular}{lll}
\hline $\begin{array}{l}\text { ABO blood } \\
\text { groups* }\end{array}$ & $\begin{array}{l}\text { Preeclampsia patients } \\
\text { with hypertension } \\
\text { postpartum, } \mathbf{n}(\%)\end{array}$ & $\begin{array}{l}\text { Preeclampsia } \\
\text { patients without } \\
\text { hypertension } \\
\text { postpartum, } \mathbf{n}(\%)\end{array}$ \\
\hline O Rh $(+)$ & II $(55)$ & $5 I(22)$ \\
Non-O Rh $(+)$ & $9(45)$ & $179(78)$ \\
Total & $20(100)$ & $230(100)$ \\
\hline
\end{tabular}

Note: $* P=0.001$.
We investigated the association between $\mathrm{ABO} / \mathrm{Rh}$ blood groups and $\mathrm{PE}$ for a total of 250 patients. Our results indicate that women with blood group $\mathrm{AB}$ have a higher risk of PE. This finding of our study was found to be consistent with a population-based cohort study from Sweden which reported that blood group $\mathrm{AB}$ had the highest risk for $\mathrm{PE}$ (odds ratio 1.1) and also with another case-control study from Finland including 248 cases of PE which reported that women with blood group $\mathrm{AB}$ had a higher risk for PE than non- $\mathrm{AB}$ women (odds ratio 2.1), with the risk being larger for severe PE (odds ratio 2.3). ${ }^{15,16}$ The results of a meta-analysis demonstrated an association between maternal AB blood group and increased risk for developing PE. ${ }^{17}$

As stated in a previous study that an abnormal hemostasis occurs in the uteroplacental circulation of women with PE, the association between $\mathrm{AB}$ blood group and $\mathrm{PE}$ may reflect the multifactorial character of thrombus formation. ${ }^{18} \mathrm{AB}$ blood group subjects present increased levels of two important hemostatic factors, factor VIII and von Willebrand factor (VWF), and increased levels of these two hemostatic factors have been related to increased risk for thrombus formation in several conditions. ${ }^{18,19}$ The molecular mechanism of the effects of ABO on VWF is not completely understood. The most accepted hypothesis is that: ABO antigens would influence VWF glycosylation and therefore its plasma levels by preventing its proteolysis and clearance by ADAMTS13, a metalloprotease able to cleave VWF multimers. Posttranslational modification of VWF includes addition of sugar residues, the same that define ABO antigens. These sugar residues are located near the ADAMTS13 cleavage site on VWF molecule and may influence its proteolysis by steric hindrance or charge effects. ${ }^{20}$

Since PE is a multifactorial disease, other thrombophilic factors may play a role in this disease in addition to $\mathrm{ABO}$ blood group. As shown in a study, the association between factor V Leiden and non-O blood group did not increase the risk of PE. ${ }^{16}$

Another possible explanation for the effects of $\mathrm{ABO}$ blood groups on the development of $\mathrm{PE}$ has been the placental protein 13. It is an early biomarker of PE with suspected function in the maternal-fetal immune interface, and differentially binds to erythrocytes from distinct ABO groups, with strongest binding to blood group $\mathrm{AB} .^{15}$

There are many studies about the association of $\mathrm{ABO} / \mathrm{Rh}$ blood groups and PE but still there are not enough studies in the literature about the association between $\mathrm{ABO} / \mathrm{Rh}$ blood groups and developing HT after PE. Despite the significant number of studies that implicate increased blood pressure and cardiovascular risk in women following a pregnancy 
complicated by HT, there is little information about the mechanisms that link this association. ${ }^{21}$ A study showed that women with previous PE had worse endothelial function, more atherosclerosis, higher microalbuminuria, and higher uric acid levels compared with controls. ${ }^{5}$ Recent studies indicate that genetic variants at the ABO locus are associated with vascular inflammatory agents, such as soluble E-selectin, P-selectin, and ICAM-1 that are associated with HT and type 2 diabetes. ${ }^{15}$

In the second part of the study, we investigated this association and there was a significant difference between the patients developing HT after PE and PE without HT in terms of distribution of $\mathrm{ABO}$ blood groups, and the percentage of group $\mathrm{O}$ was found to be higher in patients developing HT after PE. Further studies are needed to understand the underlying biological base and the biological processes responsible for this effect.

There was a significant difference between the groups - PE patients with or without HT - in terms of ABO blood groups with $\mathrm{Rh}$ factor and the ratio of developing HT is found to be higher in the patients with $+\mathrm{Rh}$ factor.

Because the $\mathrm{ABO} / \mathrm{Rh}$ blood group phenotypes are stable throughout life time, it is important to determine the association between the $\mathrm{ABO} / \mathrm{Rh}$ blood groups and the risk of developing PE and HT after PE because of the clinical implications. The ABO blood group typing is a simple test and it is already a part of antenatal follow-up. A new study from Turkey performed by Karagoz et $\mathrm{al}^{22}$ stated that the patients with blood group AB have a higher risk for gestational diabetes and the patients with gestational diabetes of blood group $\mathrm{O}$ are under the higher risk of developing diabetes mellitus that was consistent with our results. If our findings of this study can be replicated by other studies performed on other nations in larger populations, ABO blood group phenotypes may be used as a single risk factor or in combination with other risk factors to identify individuals at high risk for possible prevention of PE and also developing HT after PE.

\section{Conclusion}

In summary, this study found that the patients with blood group $\mathrm{AB}$ have a higher risk for $\mathrm{PE}$. Considering the role of ABO blood groups on the hemostatic process and thrombus formation, prophylactic low dose aspirin may be recommended in this population in an attempt to prevent disease.

Especially, patients with $\mathrm{PE}$ of blood group $\mathrm{O}$ are under a high risk of developing HT and $+\mathrm{Rh}$ factor must also be remembered as another risk at this point and so these patients should be closely followed postpartum.

\section{Disclosure}

The authors report no conflicts of interest in this work.

\section{References}

1. Petla LT, Chikkala R, Ratnakar KS, Kodati V, Sritharan V. Biomarkers for the management of pre-eclampsia in pregnant women. Indian J Med Res. 2013;138(1):60-67.

2. Uzan J, Carbonnel M, Piconne O, Asmar R, Ayoubi JM. Pre-eclampsia: pathophysiology, diagnosis, and management. Vasc Health Risk Manag. 2011;7:467-474.

3. Duley L. The global impact of pre-eclampsia and eclampsia. Semin Perinatol. 2009;33(3):130-137.

4. Williams PJ, Pipkin FB. The genetics of pre-eclampsia and other hypertensive disorders of pregnancy. Best Pract Res Clin Obset Gynaecol. 2011;25(4-4):405-417.

5. Aykas F, Solak Y, Erden A, et al. Persistence of cardiovascular risk factors in women with previous preeclampsia: a long-term follow-up study. J Investig Med. 2015;63(4):641-645.

6. Farhud DD, Yeganeh MZ. A brief history of human blood groups. Iran J Public Health. 2013;42(1):1-6.

7. Kamil M, Al-Jamal HA, Yusoff NM. Association of ABO blood groups with diabetes mellitus. Libyan J Med. 2010;5:4847.

8. Akca Z, Mutlu H, Erden A, Buyukcelik A, Sezer EY, Inal A. The relationship between $\mathrm{ABO}$ group and glioblastoma multiforme. Med Sci. 2014;3(4):1639-1647.

9. Maxwell RD, Maxwell KN. ABO blood groups and hypertension. Br Med J. 1955;2(4932):179-180.

10. Chandra T, Gupta A. Association and distribution of hypertension, obesity and $\mathrm{ABO}$ blood groups in blood donors. Iran J Ped Hematol Oncol. 2012;2(4):140-145.

11. South J, Naldrett J. Maternal blood group A and pre-eclampsia. $\mathrm{Br}$ Med J. 1974;1(5908):641.

12. May D. Maternal blood group A and pre-eclampsia. Br Med J. 1973; 4(5894):738.

13. Hentschke MR, Caruso FB, Paulo LG, et al. Distribution of ABO and rhesus blood groups in patients with pre-eclampsia. Pregnancy Hypertens. 2012;2(3):268-269.

14. Hentschke MR, Caruso FB, Paulo LG, et al. Is there any relationship between $\mathrm{ABO} / \mathrm{Rh}$ blood group and patients with pre-eclampsia? Pregnancy Hypertens. 2014;4(2):170-173.

15. Lee BK, Zhang Z, Wikman A, Lindqvist PG, Reilly M. ABO and RhD blood groups and gestational hypertensive disorders: a population-based cohort study. BJOG. 2012;119(10):1232-1237.

16. Hiltunen LM, Laivuori $\mathrm{H}$, Rautanen $\mathrm{A}$, et al. Blood group $\mathrm{AB}$ and factor V Leiden as risk factors for pre-eclampsia: a population-based nested case-control study. Thromb Res. 2009;124(2):167-173.

17. Alpoim PN, de Barros Pinheiro M, Junqueira DR, et al. Preeclampsia and $\mathrm{ABO}$ blood groups: a systematic review and meta-analysis. Mol Biol Rep. 2013;40(3):2253-2261.

18. Higgins JR, Walshe JJ, Darling MR, Norris L, Bonnar J. Hemostasis in the uteroplacental and peripheral circulations in normotensive and preeclamptic pregnancies. Am J Obstet Gynecol. 1998;179(2):520-526.

19. Morelli VM, de Visser MC, van Tilburg NH, et al. ABO blood group genotypes, plasma von Willebrand factor levels and loading of von Willebrand factor with A and B antigens. Thromb Haemost. 2007;97(4): 534-541.

20. Bowen DJ. An influence of ABO blood group on the rate of proteolysis of von Willebrand factor by ADAMTS13. J Thromb Haemost. 2003; 1(1):33-40.

21. Intapad S, Alexander BT. Pregnancy complications and later development of hypertension. Curr Cardiovasc Risk Rep. 2013;7(3):183-189.

22. Karagoz H, Erden A, Ozer O, et al. The role of blood groups in the development of diabetes mellitus after gestational diabetes mellitus. Ther Clin Risk Manag. 2015;11:1613-1617. 


\section{Publish your work in this journal}

Therapeutics and Clinical Risk Management is an international, peerreviewed journal of clinical therapeutics and risk management, focusing on concise rapid reporting of clinical studies in all therapeutic areas, outcomes, safety, and programs for the effective, safe, and sustained use of medicines. This journal is indexed on PubMed Central, CAS,

EMBase, Scopus and the Elsevier Bibliographic databases. The manuscript management system is completely online and includes a very quick and fair peer-review system, which is all easy to use. Visit $\mathrm{http}: / / \mathrm{www}$.dovepress.com/testimonials.php to read real quotes from published authors.

Submit your manuscript here: http://www.dovepress.com/therapeutics-and-clinical-risk-management-journal 